Article

\title{
The Roads, Tracks, Paths, and Ropeways of the First World War: An Opportunity to Preserve, Maintain, and Valorize Alpine Landscape
}

\author{
Maria Paola Gatti ${ }^{1, *(1)}$ and Antonella Indrigo ${ }^{2}$ (1) \\ 1 Department of Civil, Environmental and Mechanical Engineering, University of Trento, 38123 Trento, Italy \\ 2 Project Cultures Department; University IUAV of Venice, 30135 Venice, Italy; antonella@indrigo.it \\ * Correspondence: mariapaola.gatti@unitn.it
}

Received: 9 December 2019; Accepted: 3 February 2020; Published: 6 February 2020

\begin{abstract}
This research aims at understanding how to reuse infrastructure built in the Alps during the First World War to facilitate access to upland areas, increasingly used for tourism, sports, and hiking, but neglected in terms of maintenance. In other words, the main goal here is to improve and preserve the state of the mountain environment (including forests, meadows, pastures, etc.) through the reuse of historical infrastructures such as ropeways and mule tracks. Any form of reactivation of the now abandoned military logistics system, consisting of roads, mule-tracks, paths, and ropeways would enable the currently depopulated places to initiate a new and virtuous cycle. In this way, controlled planning would allow adequate maintenance to be provided for those natural and anthropic landscapes which have been progressively deprived of a productive role. The condition of abandonment and the lack of maintenance of the Alpine landscape have allowed the abundant rains of recent years, which are the result of climate change, to damage the forests of northern Italy and cause a series of hydrogeological landslides. That said, it could be assumed that the conversion of abandoned mule tracks, paths, and ropeways would not only help preserve a healthy Alpine environment but would also contribute to control these phenomena. Furthermore, it would be a way of giving new use to the historical infrastructures that played such an important role in the early 1900s, recognizing in this way their historical value. The transformation of the Alpine landscape and the building of the infrastructures involved all the lines of the front which were located on the mountains. Therefore, the choice of the Asiago Plateau, a portion of the Venetian Prealps comprised between the provinces of Vicenza and Trento, is just paradigmatic, namely, it reflects the features of a more widespread situation. However, the laws promoted by the Italian state have, as their objective, the recovery and maintenance of forts, trenches and buildings of historical value, but do not include the mountain territory that surrounds them. Therefore, reusing the infrastructures from the First World War would allow the whole landscape to be kept active.
\end{abstract}

Keywords: reuse; circular economy; Alpine environments; military logistics system; landscape management; sustainable infrastructure

\section{Introduction}

Ten years ago, the European Landscape Convention [1] provided a definition of landscape which includes the concept of natural and anthropic environment and gives birth to many international debates aiming at the enhancement of the quality of the landscape itself $[2,3]$, since the latter requires continuous dynamic actions whose main goal its "protection", "management", and "planning" [1].

The critical factors for the upland landscape of the Italian Alpine Arch [4], the section of the Alps range system defining the current northern Italian border, include abandonment, depopulation and 
poor maintenance of sites where there are grand buildings (i.e., forts), important forestry resources, and above all, an economy that could be incentivized and developed creating new jobs.

In addition, climate instability is producing even more abundant precipitation, reaching catastrophic proportions in recent years [5]. Sustainable management of these resources is becoming urgent and its solution involves environmental, social, and economic objectives [6]. Given this situation, correct land management now has a central role to play in mitigating the risk of geological and hydrogeological vulnerability and preserving towns, villages, and the landscape itself.

The reuse of roads, mule-tracks, paths, and ropeways built during the First World War would open up the possibility of sustainable tourism by facilitating the fruition of upland areas, the maintenance of the forests, and the supply of timber. This timber could be used for various purposes, such as the construction and the of buildings production of energy from biomass in accordance with the European Commission Circular Economy Action Plan, launched in 2015 and still underway [7]. Incidentally, by the concept of ropeway, it is understood a form of aerial lifting device used to transport equipment in mountain areas [8].

Throughout the Alpine Arch during the first years of the last century, barely popular at that time, the Italian and Austro-Hungarian armies built long stretches of paved roads, dirt roads, mule-tracks, paths, narrow gauge railways, and ropeways to supply the troops at the front [9].

This infrastructure was developed to form an extensive network connecting upland areas with the valley floor. This was a network that enabled small and large items to be transported rapidly, accessible in all seasons, in the heat, in the cold, and in the snow.

Of all this heritage [10], many places of remembrance such as trench lines have survived until today and have become destinations for historical and nature tourism. On the other hand, the dirt roads and mule-tracks that reached high up into the mountains have often become simple paths. Thirdly, the infrastructure for the ropeways that once transported both provisions and timber has been abandoned.

During the First World War the knowledge of places and the urgency of war allowed the armies to identify the best strategic areas to locate the different infrastructures, in respect of the local orography and geography.

This knowledge represents a cultural background [11] that could be productively reactivated for different purposes. In this sense, the research recognizes that the reuse of these roads, tracks, and ropeways could become a way to control and valorize today's forests.

The analysis focuses on the Asiago Plateau, a part of the Alpine landscape stretching for $600 \mathrm{~km}$ between the provinces of Vicenza and Trento and comprising a series of peaks over $2000 \mathrm{~m}$ high. On the other side, this is far from being an isolated case, for the military logistic system of that place is common to all the rest of military fronts present in the Alpine Arch.

\section{Materials and Methods}

The research was carried out through an extensive literary review and by comparing maps and databases of different ages. In addition, both Italian and European Legislation and Guidance were taken into consideration.

To understand the transformation of the landscape from a totally natural to an anthropic place, we used the cartographic bases from the late 19th century, the beginning of the 20th century, and from modern time. Furthermore, in order to understand how the transformation of the Alpine landscape took place, the infrastructures built during the First World War and their methods were analyzed.

From the end of the 19th century to the end of the war, the Italian Military Geographic Institute produced several maps to monitor changes in the territory. Newly built roads, fortresses, fortifications, etc. can be seen year after year.

These 1:25000 scale maps from the years 1886, 1902, 1910, 1918, 1927, 1935, 1959, and 1969 were analyzed and overlapped in order to be compared. 
The Military Geographic Institute also made several air flights that were used in the research, precisely the 1954 GAI flight and the 1967 IGM flight, whose aerial photographs describe the transformation of the landscape. All original materials are saved in the main branch of the Institute located in Florence.

The maps were subsequently overlapped, analyzed, and finally redrawn to highlight some aspects of the changes that took place. Contemporary maps were also overlaid. This analysis made it possible to understand which infrastructures are still in use, as in the case of roads. The maps of the roads, ropeways, and destroyed forested areas were redrawn on the cartographic bases already mentioned by one of the authors (Indrigo A.) and are proposed in Figures 1-4.

Vintage photographs also helped understand this change.

The georeferenced interpretation of the territory and knowledge of the application of the laws issued by the Italian State highlighted the need to preserve the forests of the Alpine Arch through the reuse of some networks employed during the war.

The cartographic research focuses on the Asiago Plateau, a portion of the Venetian Prealps comprised between the provinces of Vicenza and Trento, which was theatre of numerous clashes between the two opposing armies.

Historical artefacts have been only partially recovered and much of the infrastructure network has been abandoned.

Beyond the cartographic analysis, the research describes the dimensions of the infrastructures built in that period.

Then, it analyses the reuse practices implemented in Italy.

Finally, it hypothesizes a possible reuse of these infrastructures for the maintenance of the Alpine landscape, now in a state of neglect.

\section{Results}

War has always accelerated knowledge in all sectors: from engineering to architecture, planning, construction techniques, and even communications.

However, the events of the First World War have mainly been analyzed from historical to artistical [12-18] points of view, and in this regard, countless publications may be quoted. The infrastructures built throughout the Alpine Arch have scarcely been considered.

The latter, however, irreversibly modified the landscape and laid the foundations for today's land use.

In a short period of time, innumerable defensive and tactical works were in fact constructed together with a dense logistics network to supply the vast number of troops [19]. Works began on a mammoth scale, both to construct the front and the defense lines of and to build new roads, bridges, railways, and ropeways. Military hospitals were founded inside the towns, factories were converted for the production of weapons, timber, food etc. and aqueducts were built [19]. In upland areas, forts and fortifications were expanded while military quarters and barracks were established in towns and villages. All the mule tracks, paths, and ropeways are now abandoned.

Construction of works to "solidify" the frontier between Italy and the Austro-Hungarian Empire began before the outbreak of war. In the beginning, it involved the construction of numerous forts and the modernization of the existing ones, with the aim of achieving thorough control of the country borders [20].

In the case of the territory of the Asiago Plateau, the forts of Punta Corbin, Monte Verena, Cima Campolongo, and Monte Lisser were built.

Smaller structures were also built, such as the Stella redoubt, the Bocchetta Portule cave batteries, and the Monte Rasta and Canove di Sotto batteries with lateral defenses [21]. To build these fortifications, military railways, mule-tracks, roads, and ropeways had to be constructed to transport the materials necessary and supply the soldiers working there. From their high positions, these forts and fortifications controlled and dominated the territories below. 
When hostilities broke out, various roads were constructed with different sizes, techniques, and surfaces to reach the front lines high up in the mountains.

The network of military infrastructure was designed by military engineers following complex manuals [22] and constructed by soldiers, prisoners, and civilian workers.

The military roads were classified according to their surface, which could be either natural (dirt roads) or artificial (paved roads). The majority of the roads were intended for simple transit only.

They were therefore divided into paved roads adopting the surfacing technique invented in 1820 by MacAdam [23], dirt roads, mule-tracks, and paths practicable on foot only. The innovative technique adopted by the Scottish engineer consists of making roads as waterproof as possible, and in this way, it facilitates the transit of all the means of transport working on wheels.

As shown in Table 1, the precise dimensions of each road or track were established in relation to the orography, the travelling speed required, and the type of use.

Table 1. Road dimensions.

\begin{tabular}{cccc}
\hline Type of Road & Width & Maximum Gradient & Minimum Radius of Curvature \\
\hline Paved roads & $4-8 \mathrm{~m}$ & $8 \%$ & $30 \mathrm{~m}$ \\
Dirt roads & $2-4 \mathrm{~m}$ & $18 \%$ & $2 \mathrm{~m}$ \\
Mule-tracks & $0.80-1 \mathrm{~m}$ & $20 \%$ & $1 \mathrm{~m}$ \\
\hline
\end{tabular}

Considering that in the mountains there is a huge difference of altitude, the roads were planned with numerous hairpin bends with a radius of curvature of sometimes as little as one meter, providing there was a corresponding widening of the road to allow the vehicles to turn. Consecutive hairpin bends were separated by 10 meters of straight level road [23].

With respect to the natural terrain, military roads could be:

- flush, when the road bed was at the same level as the natural ground,

- raised, when the road bed was at a higher level,

- sunken, when the road was sunken below ground level,

- hillside, when the section of the road was partly raised and partly in an open trench.

The surface of carriageable roads had to be stable and very durable. The central carriageway was therefore constructed with a layer of coarse gravel about $20 \mathrm{~cm}$ thick (road base) and a layer of finer gravel (gravelling) [23].

Depending on the category, the flow of rainwater modified the configuration of the road surface. If the road was flush, raised, or sunken, the recommendation was to create a steeply cambered profile with the central part raised, with respect to the sides for about 1/20 of the width of the carriageway. When the road crossed built-up areas, the preference was for a "cradle" profile with a single gutter in the center of the carriageway. In the case of roads on a hillside, a "pitched" profile sloping on the highest side was adopted.

The carriageways were flanked by shoulders of a width based on an anthropometric module $(60-120 \mathrm{~cm})$ to allow the passage of pedestrians, with a very hard surface (generally stones laid on edge) to facilitate the flow of rainwater and avoid landslips [23].

As well as their construction, maintenance of the roads was also of vital importance to guarantee transit. In fact, they were constantly monitored and modernized to keep them fully efficient and fit for the movements.

With the outbreak of hostilities, the construction of defense infrastructure intensified. Numerous divisional centers were therefore constructed, closely connected to the smaller centers, and generally located near the defense lines.

Troop quarters could be found everywhere and were built with different techniques, such as dry-stone huts with a single-pitch iron roof, or buildings of a considerable size constructed using 
the Blockbau technique in wood or plastered masonry, and, of course, long stretches of trenches and artillery posts.

On the Asiago Plateau, the most important Austrian logistics base was constructed at Monterovere and Vezzena, and subsequently became the nerve center for the units. A number of divisional service centers were also set up in Casare Larici, Ghertele, and Campo Gallina, nicknamed the "Pompei of the Great War" for the large number of remains still visible. In the part of the Asiago Plateau controlled by the Italians, the divisional centers were concentrated at Campo Spa, Foza, Campomezzavia, Granezza, and Campiello [21]. The Austrian army also intensified the construction of new roads. To give an idea of the scale of this colossal enterprise, the total length of the road network was estimated to be more than $400 \mathrm{~km}$ of new roads (including the conversion of old mule-tracks into paved roads).

The Austrian army constructed the Eungenstrasse, connecting Larici with Bocchetta Portule and Monumenti, and the Kaiser Karlstraße across the Portule valley, through Campo Gallina as far as Campigoletti and Monte Ortigara [21].

The Italian army also built a number of roads, connecting Roccolo Cattagno to Cima Campanella, and then on to Cima della Caldiera at an altitude of $2100 \mathrm{~m}$ AMSL. They also built the roads from Calvene to Monte Cavalletto, from Bassano to Tortima, from Valstagna to Foza with its 21 hairpin bends and three tunnels, and finally, from Gallio to Foza and Enego [21]. At the same time, a dense network of mule-tracks was created, linking all the most unexplored points of the plateau. At the end of the war, these mule-tracks were partially destroyed by lack of maintenance and the advance of mountain vegetation (Figure 1).

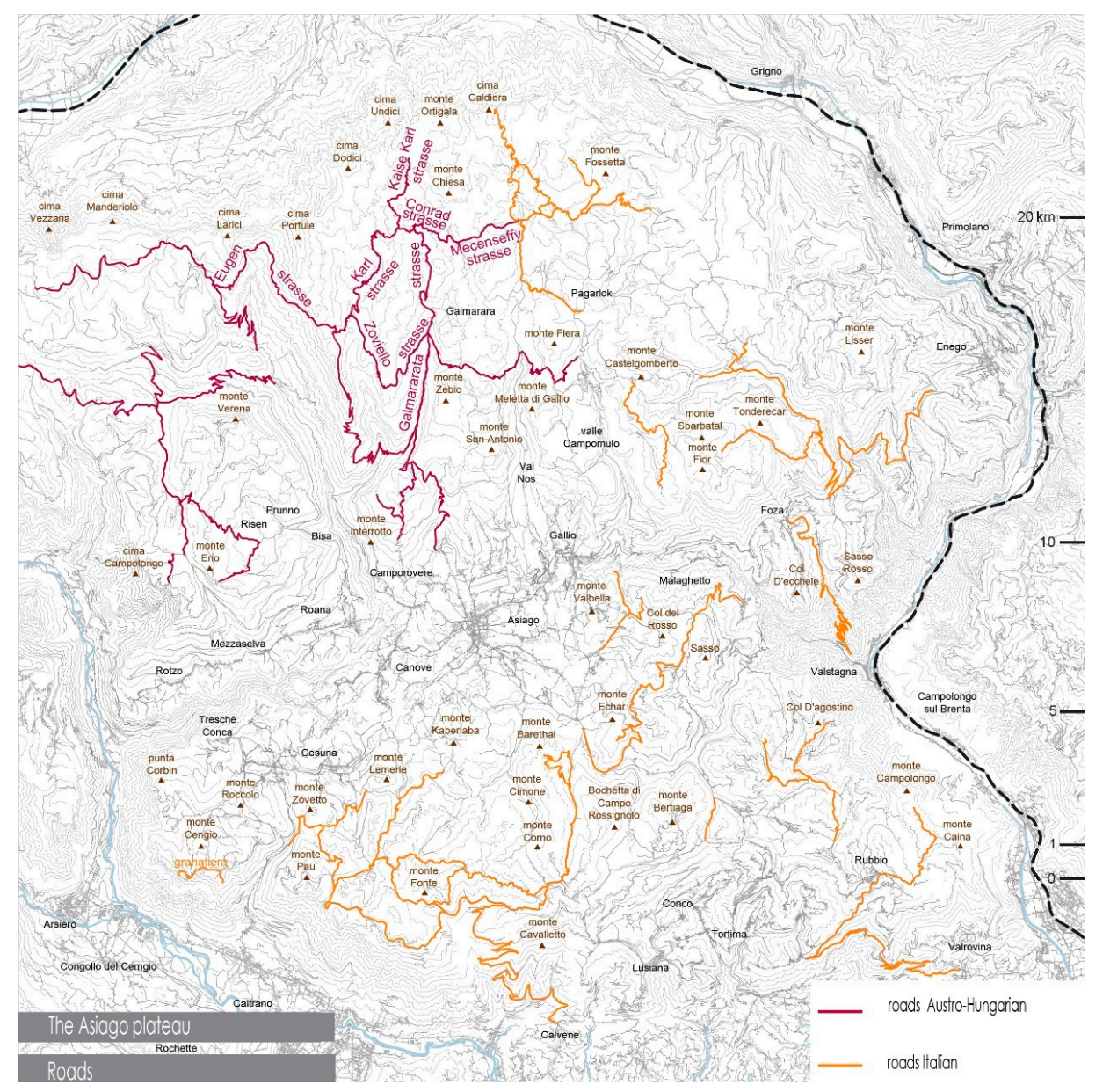

Figure 1. The Asiago Plateau: the roads built by the Austro-Hungarian army (yellow) and those built by the Italian army (red). 
In addition to this network, these slopes were also crossed by another high-altitude network of ropeways to transport raw materials, provisions, ammunition, building materials, and weapons. The rope transportation, generally known as "Seilbahn", was managed by corps of railway engineers called "telefori" [8] and was mainly used in mountainous areas, and consisted of one or more aerial transport ways and as many ropes stretched between two stations and supported in between by one or more poles. The ropeway devices could be made by one, two or three ropes: they could lift different weights and could be operated either manually or mechanically. Furthermore, they comprised three main types. The first type, called "Nachschubsbahnen" by the Austro-Hungarian army and heavy ropeways by the Italians, had as a starting point railway stations, important crossroads, and warehouses where the supplies for the different front units were stored. The second type, called "Verteilungsbahnen" by the Austro-Hungarian army and field ropeways by the Italians, involved rope devices that were useful to supply the intermediate warehouses located in safe positions compared to the front lines. The third type, called the "Stellungsbahnen" by the Austro-Hungarian army and light ropeways by the Italians, were light ropeways often manually operated that reached the most advanced positions compared to the front lines [8]. The general idea of rope transportation implied some preliminary work: on the mountains, once the layout was designed, the ropes were carried from one point to the other and the soil in between was cleared from trees. For the construction of a one-rope device, it normally took three or four weeks, while for a two-rope device, a period of seven or eight weeks was necessary [8].

In 1916, the Austrians constructed a series of ropeways connecting the depots of Valsugana and Val d'Adige to the logistics centers of Monterovere Vezzena and Val d'Assa. The field ropeways started out from Ghertele. Among these temporary structures, an important role was played by both the T30 "Kempelban" connecting Larici to Cima Porule, then continuing to Pallone and Busa del Cavallo, and the T 31 connecting Campo Bianco to Pusterle and Bocchetta di Portule, and then continuing to Corno Verde and Corno Bianco [21].

In 1917, this aerial infrastructure consisted of six heavy ropeways for a total length of $67.520 \mathrm{~km}$, six field ropeways for a total length of $31.150 \mathrm{~km}$ and 14 light ropeways for a further $48.10 \mathrm{~km}$ [21]. These figures show the enormous work carried out in very few years by the two armies in an area made difficult by its orographic configuration and altitudinal range [22]. Finally, along with these structures, there was also a massive water network supplying the logistics centers and soldiers posted high up in the mountains, compensating for the lack of springs (Figure 2).

At the beginning of the 20th century, there were various varieties of trees on the plateau, including Norway spruce, silver fir, beech, larch, and mugo pine. Each year, $35,000 \mathrm{~m}^{3}$ [24] of timber was destined for trade with the plain. The start of deforestation coincided with reinforcement of the fortifications along what was then the border between the Austro-Hungarian Empire and Italy, today the border between the regions of Trentino and Veneto. The majority of the trees were felled to open up a view across the valley floor to control enemy movements.

The timber was used for temporary works to build roads, mask structures, construct trenches, walkways, huts, ropeways, etc., and to fuel the field kitchens for more than a million active soldiers stationed in the area.

During the war, the forests were devastated by bombings to the point where, according to reports of war damage, by the end of the conflict, 18,656 hectares of forest had been damaged, including 4680 razed to the ground, 1936 almost destroyed, 3781 severely damaged, and 5399 damaged, with only 2860 remaining intact [24]. Both privately and publicly owned forests were affected, with the former, located near built-up areas, being more severely hit by the explosions, fires, and felling for war purposes. 


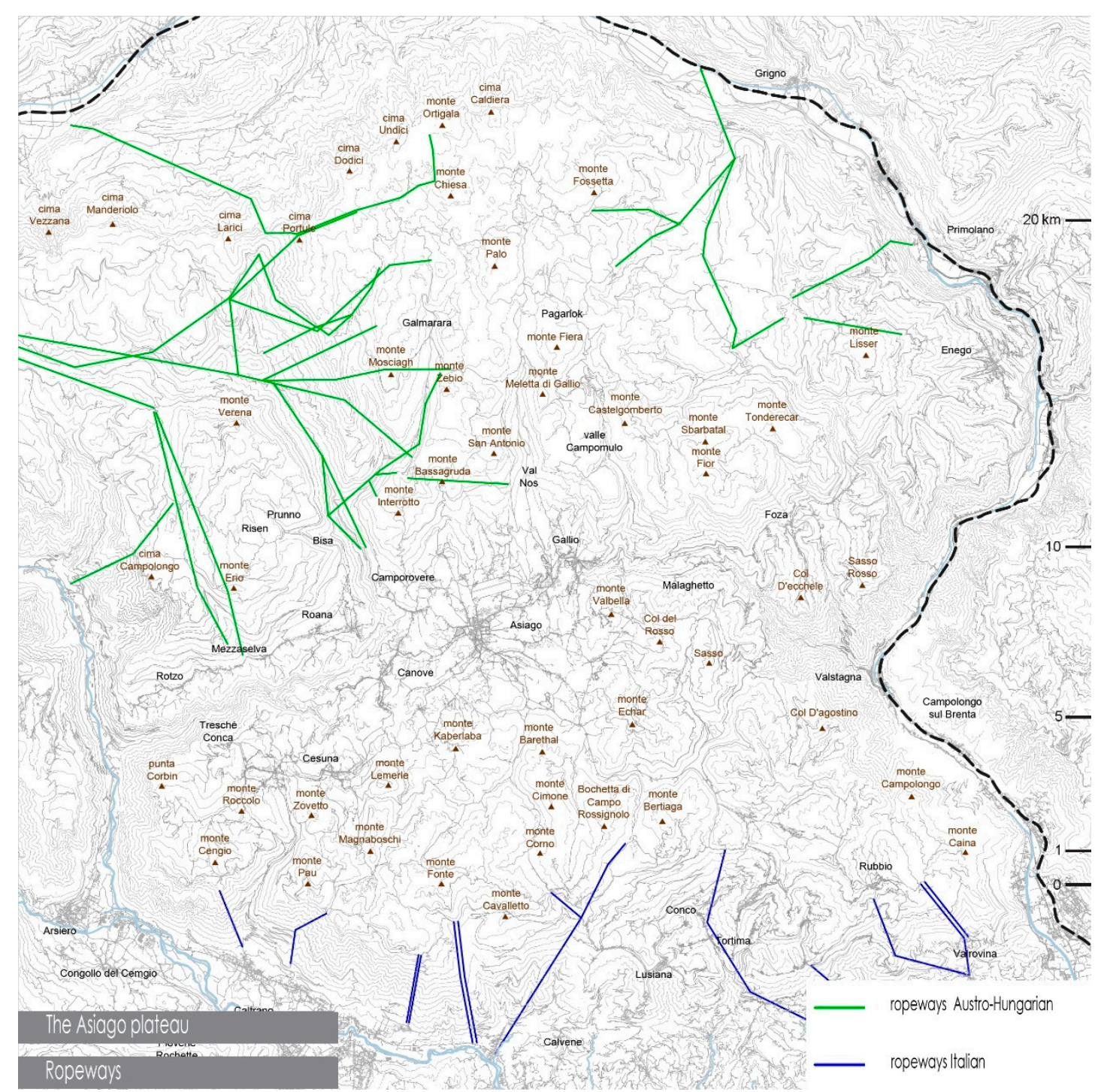

Figure 2. The Asiago Plateau: the ropeways built by the Austro-Hungarian army (green) and those built by the Italian army (blue).

These figures demonstrate the scale of the landscape destruction. Cartographic reconstructions show the destroyed forested areas and the movement of the front. In the municipality of Asiago, the areas affected were near the town, in the Echar, Barenthal and Kaberlab strip, the Monte Interrotto, Bassagruba and Sant'Antonio strip, and high up in the mountains near Mount Zebio Monscagh, Galamarara, and Portule [25].

The damage caused to the forests during the conflict was exacerbated by two important factors that led to the felling of 440,000 $\mathrm{m}^{3}$ [25] of timber between 1915 and 1926, making reconstruction even more difficult. The first factor was determined by the shrapnel that had penetrated the remaining trunks, making them unusable for cutting. The second factor was the proliferation of parasitic wood beetles attacking weakened trees (Figure 3). 


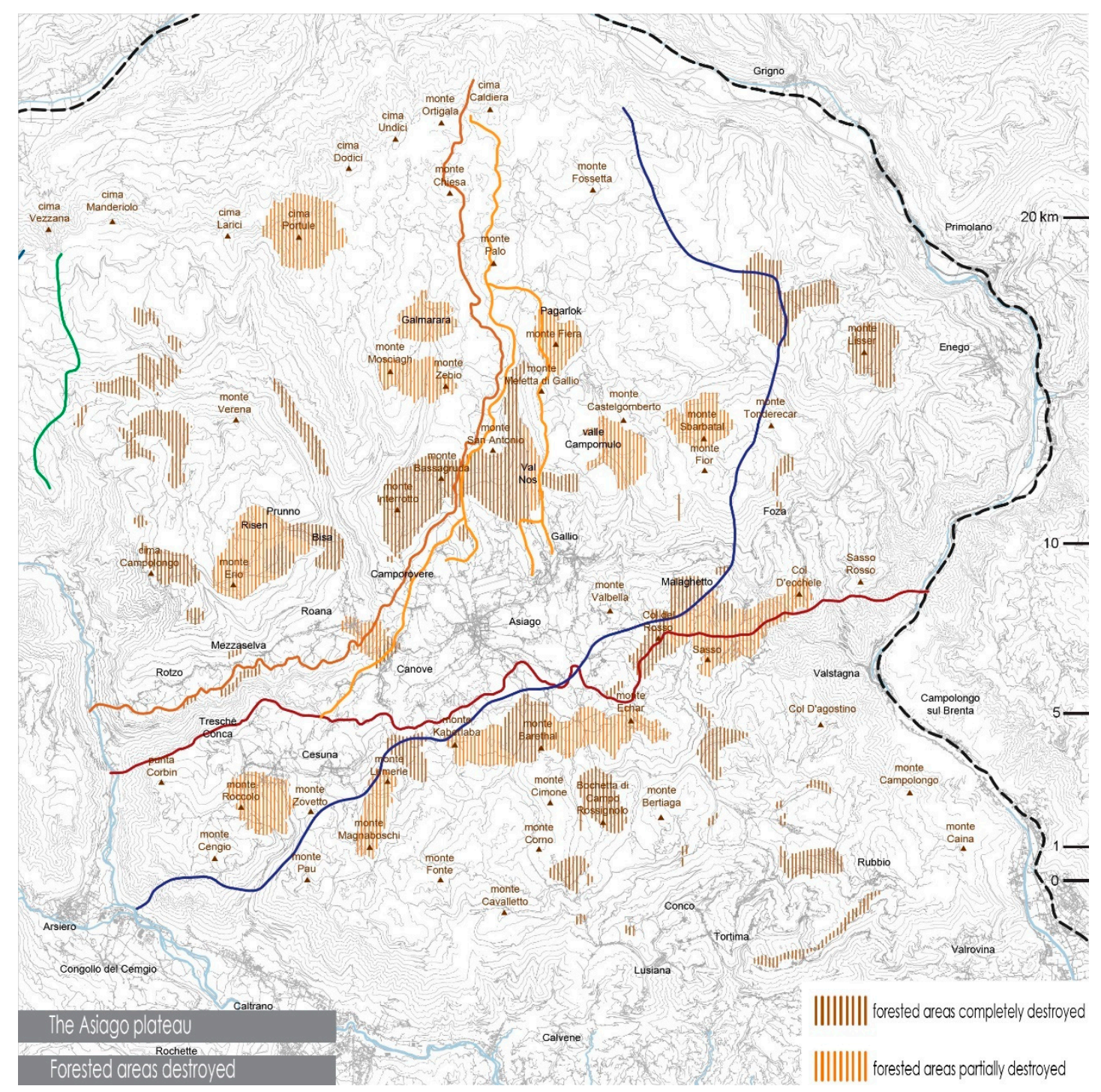

Figure 3. The Asiago Plateau: the map shows the intersection between the forested areas completely destroyed (dark brown) and partially destroyed (orange) and the movements of the front. The pale blue line shows the Austrian front on 15 May 1916; the green line shows the front of the Italian advance on 15 May 1916; the dark blue line shows the Italian front on 16 June 1916; the brown line represents the Austrian front in June 1917; the yellow line represents the Italian front in June 1917; the red line represents the Italian advance in June 1918.

Work to reconstruct the forests began that same year. To cultivate the plants to be replanted, the "Vivaio Mosca" nursery near Asiago was set up to produce the seedlings, together with 14 "civic nurseries" where the seedlings were transplanted. The most widely cultivated species was the Norway spruce, preferred to the silver fir and beech for the plasticity of the trunk and ease with which it could be grown in the nursery.

By the end of the 1930s, reforestation had reached a good point.

Taking a leap forward in time, between 1945 and 1965 [25], a further 1370 hectares of bare ground were reforested, and 4500 hectares of degraded forest were reconstructed, also using other species of trees such as larch, white, Austrian pine, and beech. Images from the time clearly show the extent of the anthropic factor in this transformation of the mountain environment. Although today they are no longer visible, the trees planted in rows remained a characteristic feature of the area for a considerable time, a demonstration of the important work of reconstruction extended to the environment (Figure 4). 


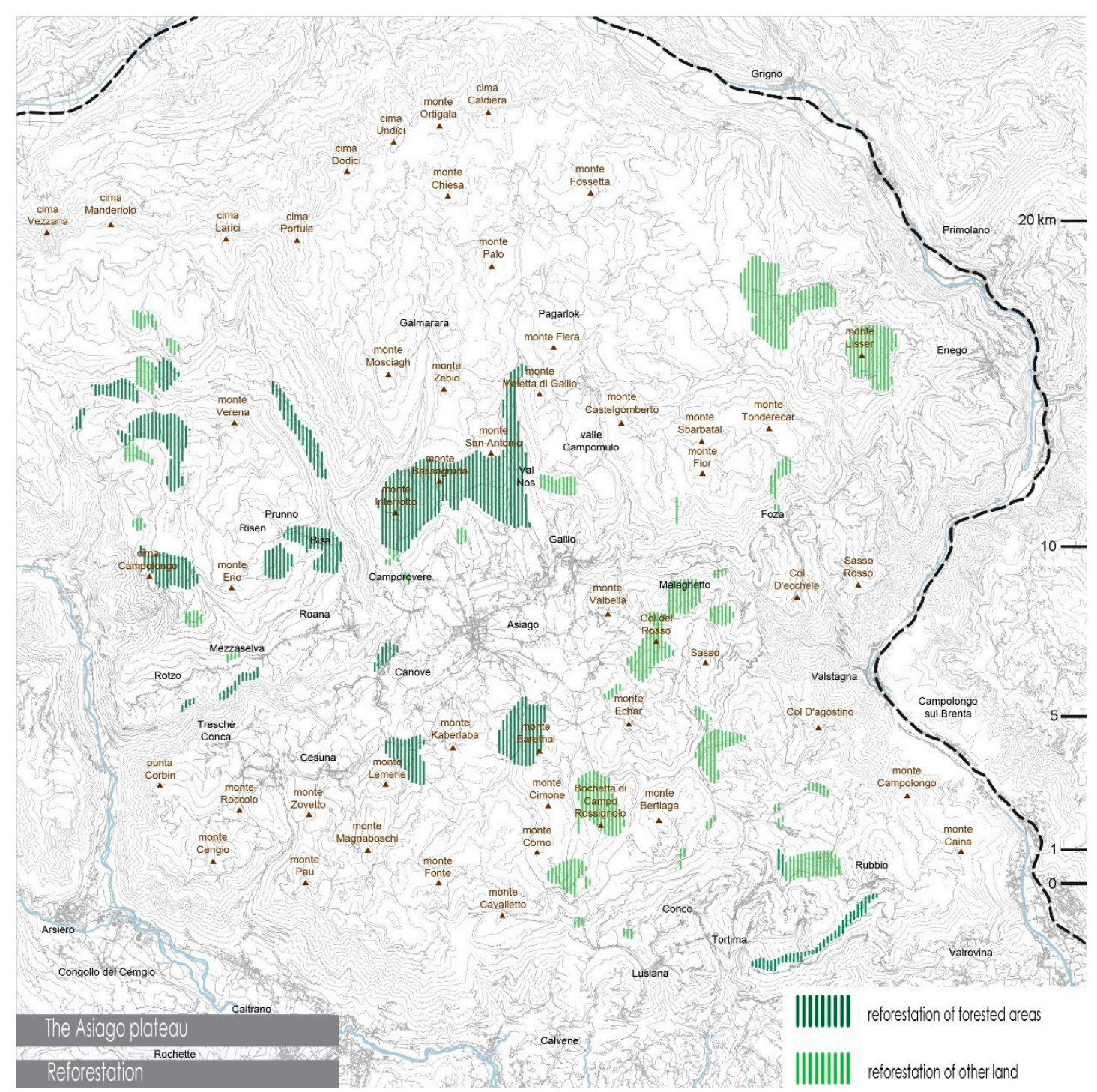

Figure 4. The Asiago Plateau: reforestation of forested areas (dark green) and reforestation of other land (pale green).

The construction and transformation of the territory that started at the beginning of the 1900s involved not just the plateau, but also all the upland areas of the front. The idea of recovering and organizing the abandoned infrastructure into a system and restoring the intermodal interchanges to improve the health of the landscape today appears a feasible course of action.

\section{Discussion}

The historical analysis of these constructions allows virtuous and sustainable scenarios for reuse of infrastructures to be hypothesized. The Alpine landscape has been abandoned and poorly maintained for a long time and this has produced frequent instabilities. However, it must be emphasized that some actions have already been carried out through the approval of laws.

In Piedmont, Law no. 9 of 18 February 2010 "Initiatives for the recovery and valorization of abandoned military roads" states the creation of historical, cultural, tourism, and sports itineraries, including through interventions and initiatives the recovery and valorization of the networks of First World War infrastructure and their inclusion in hiking and trekking circuits. As stated in article 2 of the law, the Piedmont Region promotes: 
(a) measures to recover abandoned military roads, with particular attention to regularizing the roadbed, water regulation, restoration of gutters, and all other measures necessary to limit their degradation;

(b) projects to identify abandoned military roads for inclusion in the network of hiking and trekking itineraries, as an added value and complement to the environments they cross;

(c) initiatives to foster knowledge of the historical value of the abandoned military roads and associated fortifications, including through the production of films involving historical events set in the local area, the setting up of historical and ethnographic museums, and organization of re-enactments of the events and battles taking place in the area;

(d) the surveying and cataloguing of abandoned military roads in the western Alps, with the involvement of provincial authorities, upland authorities, municipalities, and the relevant sections of the "Club Alpino Italiano".

Article 4 of the Law "Usability of abandoned military roads" establishes the criteria for using the abandoned military roads.

A document of just a small number of articles, which, nevertheless, managed to activate the process of enhancement of the individual works, took into consideration infrastructures such as the road ones and promoted a revitalization and a wider reuse of the landscape.

Other initiatives have been launched in other regions. For example, in Trentino in the early 1980s, the Service in Support of Employment and Valorization of the Environment (an organ of the provincial authority) initiated the creation of a Peace Trail, an itinerary from the Stelvio to the Marmolada, linking historical sites from the First World War along what was the Trentino-Tyrolean front. As part of this initiative, long stretches of trenches have been recovered and cleared, military posts and strongholds have been uncovered, tunnels and walkways have been freed, and paths and connecting elements have been created and equipped with specific signs.

Again in the Trentino, following the exceptional weather events that hit the whole of northern Italy in 2018, uprooting and destroying a large part of the forests, the Department for Civil Protection allowed and recommended the setting up of temporary ropeways and logging plant.

This way of coping with a catastrophe could become a stable modus operandi for implementation not only during contingencies. The restoration of mule tracks (now transformed into paths) and their reuse could become a way of implementing constant and virtuous monitoring of the Alpine landscape. In addition, the use and restoration of ropeways to transport timber and in support of forestry activities would contribute to valorizing the landscape and restoring the intermodality that served other purposes during the war. All this would create a productive cycle which would involve mountainous places in a state of semi-abandonment.

\section{Conclusions}

This research leads to the conclusion that, if reused, the now abandoned Alpine military logistics system could represent an opportunity to preserve and take care of the Alpine landscape.

The European Parliament has often discussed this [26], acknowledging the environmental, economic, and social role of forests against soil erosion and in the context of the water cycle, the climate, and the protection of biodiversity. Last but not least, it acknowledged it as a possible generator of direct and indirect economic resources. Forest maintenance is in fact not linked exclusively to land stabilization, but also to timber production and the possibility of initiating a virtuous economic circle that would allow jobs to be created in currently abandoned upland areas.

It is once again evident that the project to safeguard the historical heritage of the First World War must be extended across the territory to also include structures, infrastructure, and landscape.

As stated at the beginning of this article, the Alpine landscape, both natural and artificial, has strongly anthropic foundations given that it was reconstructed after the conflict and therefore necessitates constant maintenance. Recognizing and implementing these practices would mean re-appropriating that part of the upland territory that has been forgotten in recent years. 
Finally, restoring that type of infrastructure, modifying the dimensions in line with the size of today's vehicles, would also give this fragment of history back to contemporaneity, once again confirming the visionary nature of that military strategy.

The objective of all the measures promoted to date, including those covered by the Law on the "Protection of the historic heritage from the First World War" [27], is the restoration, recognition, and valorization of a number of structures of historic value, such as forts, fortifications, sections of trench, etc. Even before this, fortified buildings, entrenched camps, field batteries, etc. had been protected and safeguarded [28] by a constraint recognizing their artistic historical value.

In all this, no consideration has been given to the territory surrounding these architectural structures, which remain isolated elements even after restoration.

Preservation and safeguarding of the heritage from the First World War have so far been concentrated on the individual object, while it still lacks an overall vision. It has now become urgent to safeguard the forests surrounding the forts, fortifications, entrenched camps, etc., that played such an important economic and tactical role during that period.

It is therefore fundamental to shift attention from the individual element to the network that made it possible to reach upland areas of the Alps and to acquire an overall vision that also extends to preservation of the forests, through interdisciplinary measures enabling this important heritage to be recognized, maintained, and valorized.

Author Contributions: Conceptualization, data curation, writing-review and editing, supervision, M.P.G.; conceptualization, resources, data curation, writing —original draft preparation, writing - review and editing, cartographic drawing with the use of IGM information, A.I. All authors have read and agreed to the published version of the manuscript.

Funding: P.S. 17/21 F.A.M.A.

Conflicts of Interest: The author declare no conflict of interest.

\section{References}

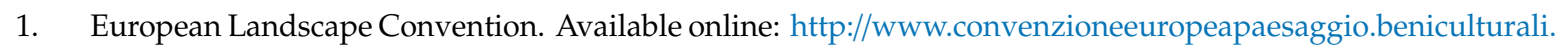
it/uploads/2010_10_12_11_22_02.pdf (accessed on 30 November 2019).

2. Council of Europe Landscape Convention. Available online: https://www.coe.int/en/web/landscape (accessed on 30 November 2019).

3. Decimo Anniversario Della Convenzione Europea del Paesaggio. Available online: http://www. convenzioneeuropeapaesaggio.beniculturali.it/index.php?lang=en (accessed on 30 November 2019).

4. Rosner, W.R. Fortificazione e Operazione. Lo Sbarramento Degli Altipiani di Folgaria, Lavarone e Luserna; Curcu \& Genovese: Trento, Italy, 2016.

5. Iacovino, F.; Nocentini, S. Selvicoltura e tutela del territorio. In Proceedings of the Second International Congress of Silviculture; Accademia Italiana di Scienze Forestali: Firenze, Italy, 2014.; Accademia Italiana di Scienze Forestali: Firenze, Italy, 2014.

6. François, N.; European Parliament. The European Union and Forests, 2019. pp. 1-7. Available online: http://www.europarl.europa.eu/ftu/pdf/it/FTU_3.2.11.pdf (accessed on 30 November 2019).

7. European Commission. Report from the Commission to European Parliament, the Council, the European Economic and Social Committee and the Committee and the Committee of the Regions on the Implementation of the Circular Economy Action Plan. Available online: https://eur-lex.europa.eu/legal-content/EN/TXT/ PDF/?uri=CELEX:52019SC0090\&from $=E N$ (accessed on 30 November 2019).

8. Longhi, L.; Zandonati, A. Teleferiche Dell'11a Armata Austro-Angarica Dall'Adige al Brenta, Museo Storico Della Guerra di Rovereto; Edizioni Osiride: Rovereto, Italy, 2013.

9. Sigurtà, D. Montagne di Guerra, Strade di Pace. La Prima Guerra Mondiale dal Garda all'Adamello: Tecnologie e Infrastrutture Belliche, Storia Dell'architettura e della Città; Franco Angeli: Milano, Italy, 2017.

10. Quendolo, A. Paesaggi di Guerra. Memoria e Progetto; Gaspari Editore: Udine, Italy, 2014.

11. Iorio, A. Il Riciclo Strategico. Memorie Della Grande Guerra e Stratificazioni del Paesaggio Veneto Contemporaneo; Aracne: Roma, Italy, 2016.

12. Isnenghi, M.; Rochat, G. La Grande Guerra 1914-1918; Il Mulino: Bologna, Bologna, 2008. 
13. Marco, A. Le Montagne Della Patria. Natura e Nazione Nella Storia d'Italia. Secoli XIX e XX; Einaudi: Torino, Italy, 2013.

14. Leoni, D. La Guerra Verticale. Uomini, Animali e Macchine sul Fronte di Montagna 1915-1918; Einaudi: Torino, Italy, 2015.

15. Montini, M.; Alpini. Parole e Immagini di un mito Guerriero; Laterza: Roma, Italy, 2008.

16. Jünger, E. Nelle Tempeste di Acciaio; Guanda: Milano, Italy, 1995.

17. Daly, S. The Futurist Mountains': Filippo Tommaso Marinetti's Experiences of Mountain Combat in the First World War. Modern. Italy 2013, 18, 323-338. [CrossRef]

18. Baker, S.; Mavlian, S. Conflict. Time. Photography; Tate Publishing: London, UK, 2014.

19. Ermacora, M. Cantieri di Guerra. Il Lavoro dei civili nelle retrovie del Fronte Italiano (1915-1918); Il Mulino: Bologna, Italy, 2005.

20. Indrigo, A. Costruire memoria. In 15-18 Progettare la Storia; Mimesis: Milan, Italy, 2016; pp. 144-197.

21. Corà, V. I teatri della distruzione e il paesaggio costruito, in Gli Uomini e la storia Guerra sull'Altopiano: La fine di un mondo. In L'Altopiano dei Sette Comuni; Cierre edizioni: Verona, Italy, 2009; pp. 330-332.

22. Ministero Della Guerra. Comando del corpo di stato maggiore-Ufficio istruzioni e manovre n.104. In Istruzione sui Lavori di uno Zappatore; Editore del Giornale Militare: Roma, Italy, 1912.

23. De Welz, G. Primo elemento della forza commerciale ossia Nuovo metodo di costruire le strade di; G.L. Mac-Adam: Naples, Italy, 1820; Volume 1, Appendice 1; pp. 70-79.

24. Occhi, K. La corsa del legno. Scambi commerciali tra Altopiano e la pianura in età moderna. In L'altopiano dei Sette Comuni; Cierre edizioni: Verona, Italy, 2009; pp. 252-317.

25. Lazzarini, A.; Zorvi, D. I boschi dell'Altopiano. In L'altopiano dei Sette Comuni; Cierre edizioni: Verona, Italy, 2009; pp. 233-317.

26. European Commission. Closing the Loop: Commission Delivers on Circular Economy Action Plan.10. Available online: https://ec.europa.eu/commission/presscorner/detail/en/IP_19_1480 (accessed on 30 November 2019).

27. Protection of the historic heritage from the First World War, Law no. 78 of 7 March 2001. Available online: https://www.gazzettaufficiale.it/eli/id/2001/03/30/001G0135/sg (accessed on 30 November 2019).

28. Protecting things of artistic or historical interest, Law no. 1089 of 1 June 1939. Available online: http://www.librari. beniculturali.it/export/sites/dgbid/it/documenti/Normativa/Legge_1_giugno_1939_n_1089.pdf (accessed on 30 November 2019). 